\title{
Os silêncios da História ${ }^{1}$
}

\section{The silences of History}

\author{
HENRIQUE BORRALHO \\ Professor do Departamento de História e Geografia \\ e do Programa de Pós-Graduação em Letras (UEMA). \\ jh_depaula@yahoo.com.br
}

\section{RESUMO}

O presente artigo tem por objetivo discutir os silêncios na historiografia, em várias delas, na literária, sociológica, na filosófica, mas, sobretudo, na história. Silêncio é por vezes uma forma de poder, de poder ocultar o que não deve ser estandartizado, patrimonializado, base de uma memorialística, aquilo que não pode conter o arquivo pátrio, de patrimonialização, pai, o sustentáculo de uma nação. $\mathrm{O}$ silêncio sobre certos setores e categorias sociais foi alicerçada por uma hegemonia que ditou a forma como a compreensão artística, econômica, política, cientifica e até da própria razão, de um tipo de lógus racionalizante moldando a cultura, tornando-a irretorquível, estruturante, moduladora da vida, da percepção, da sensibilidade, da existência. Por que então usar o cógito invertido, a palavra, para denunciar os silêncios? Pela mesma razão que se usa uma linguagem para ampliar, subverter, modular a própria linguagem.

Palavras-chave: Silêncio. Ocultamento. Linguagem. Inversão da fala.

\begin{abstract}
This article aims to discuss the silences in historiography, in several of them, in the literary, sociological, philosophical, but, above all, in history. Silence is sometimes a form of power, of being able to hide what should not be standardized, patrimonialized, the basis of a memorial, what cannot contain the country's archive, patrimonialization, father, the mainstay of a nation. The silence about certain sectors and social categories was based on a hegemony that dictated the way in which the artistic, economic, political, scientific and even reason itself, a kind of rationalizing logus shaping culture, making it irrefutable, structuring, modulator of life, perception, sensitivity, existence. Why then use the inverted cogito, the word, to denounce silences? For the same reason that a language is used to amplify, subvert, modulate the language itself.
\end{abstract}

Keywords: Silence. Concealment. Language. Speech inversion.

Karl Marx disse uma vez, de maneira elíptica, que os seres humanos só formulam problemas que eles mesmos são capazes de responder, querendo dizer com isso, talvez, que, se temos o aparato conceitual para formular a questão, então temos, a princípio, os meios para respondê-la.

(Terry Eagleton, $O$ sentido da vida).

\footnotetext{
${ }^{1}$ Artigo submetido para avaliação em 20/04/2021 e aprovado em 30/04/2021.
} 
Rev. Interd. em Cult. e Soc. (RICS), São Luís, v. 7, n. 1, p. 56- 79, jan./jun. 2021

Falar dos silêncios da história é falar das não falas, daquilo que não se ouve, da suspensão do que, mesmo se vendo, não se enxerga. O silêncio é uma não pronunciação, nem sempre uma omissão. O silêncio é também um gesto, às vezes, político, quando de propósito não se quer dar visibilidade a algo ou alguém que, mesmo estando ali, não é percebido, ou não pode ser percebido, ou não se quer que seja percebido.

Para Mikhail Bakhtin (2017, p. 23):

O silêncio e o som. A percepção do som (no campo do silêncio). O silêncio e o mutismo (ausência de palavras). A pausa e o começo da palavra. A violação do silêncio pelo som de modo mecânico e fisiológico (como condição da percepção); a violação do mutismo pela palavra de modo pessoal e consciente: esse é um mundo inteiramente outro. No silêncio nada ecoa (ou algo não ecoa), no mutismo ninguém fala. (ou alguém não fala). $\mathrm{O}$ mutismo só é possível no mundo humano (e só para o homem).

Na Grécia "Clássica",2, o ostracismo era uma forma de punição aos que impunham uma certa ameaça à condição política citadina. Dez anos em exílio implicava uma postura de pôr em contrição pelo oposto da fama, sinônimo de morte, olvido, limbo, esquecimento: a não escuta de ter sido exilado implicava uma não lembrança, uma não fala, logo, uma não ameaça. Os gregos tentavam alcançar a imortalidade dos deuses pelos seus feitos heroicos, pela rememoração. A imortalidade não era física, e sim, do não olvido, da luta contra o silenciamento de suas trajetórias.

O filósofo italiano Giorgio Agamben (2012, p. 110), em A ideia da prosa, sobre a ideia do silêncio, afirma:

Numa recolha de fábulas dos fins da Antiguidade lê-se: "Os atenienses tinham por hábito chicotear a rigor todo candidato a filósofo, e, se ele suportasse pacientemente a flagelação, poderia então ser reconhecido filósofo. Um dia, um dos que se tinham submetido a essa prova exclamou, depois de ter suportado os golpes em silêncio: agora já sou digno de ser

\footnotetext{
${ }^{2}$ As noções da Grécia e Roma, enquanto civilizações clássicas, são invenções do Renascimento, como forma de superação e suplantação dos muçulmanos, culturas que lhes era paralela, segundo Jean Delumeau (1994). Martin Bernal, em The Black Athena (1987) percorre a construção da ideia de cultura pautada no ocidente excluindo a África, mostrando como a Grécia se tornou ancilar paradigmático referencial de cultura, berço da civilização ocidental. Ver BORRALHO (2013).

Sobre a trajetória de como o mundo ocidental optou pelo "milagre grego", ver: ARENDT (2002), CARTLEDGE (2002), JAEGER (2003), PUGLIESI (2003), ROCHA (1982), SNELL (2002), VERNANT (2002), dentre outros. A partir destes e de outros autores, Borralho discute a questão do legado grego sobre as noções de mito, história, memória, formação do mundo ocidental, modernidade, no artigo intitulado Mito, história e contra história. Ver BORRALHO (2005).

No esteio da idealização da Grécia, enquanto sociedade modelo, estava Schlegel. Para esse filósofo alemão: “apenas entre um povo é que a bela arte correspondeu à elevada dignidade de sua destinação. Apenas entre os gregos é que a arte sempre esteve livre da força da necessidade e do domínio do entendimento; seus belos jogos eram sagrados, desde o princípio da formação grega até o último momento quando ainda persistia um hálito de autêntico espírito grego" (SCHLEGEL, 2018, p. 87).
} 
Rev. Interd. em Cult. e Soc. (RICS), São Luís, v. 7, n. 1, p. 56- 79, jan./jun. 2021

ISSN eletrônico: 2447-6498

considerado filósofo! Mas responderam-lhe, e com razão: Tê-lo-ias sabido, se tivesses ficado calado.

A fábula nos ensina que a filosofia tem certamente a ver com a experiência do silêncio, mas assumir a experiência do silêncio dessa experiência não constitui de modo nenhum a identidade da filosofia. A identidade da filosofia expõe o sem-nome, sem encontrar nisso um nome para si própria. O silêncio não é a sua palavra secreta, pelo contrário, a sua palavra cala perfeitamente o próprio silêncio.

O silêncio da filosofia e o seu não silêncio não é o mesmo na história ${ }^{3}$. Na filosofia, o silêncio precede a fala, que é antecedida pela reflexão. Segundo Eric Weil (2012, p. 586):

Isso porque a filosofia se apoderou da história não como de um objeto exterior e resistente, mas como de sua própria essência, que assim deixa de ser apenas essência, o fundo inapreensível e que sempre escapa: a história é a filosofia em devir, a filosofia expressa a realidade do homem a ser realizada na história.

O silêncio é uma forma de aporia, não passagem, ou a tentativa de não o ser. Todas as vezes que o pensamento procura uma saída, encontra uma brecha. Em seguida, o silêncio se transforma em código, gesto, expressão sobre o que supostamente poderia ser dito de forma muda.

Na história, o silêncio por vezes é ocultamento. As figuras sociais não faladas são como se não existissem, precisam ser invisíveis. Tem sido assim com pobres, mulheres, negros, negras, operários (as), trabalhadores em geral, indígenas, escravos (as), quilombolas, povos das florestas, moradores de rua, mendigos, crianças pobres, homoafetivos (as) (homossexualidades) ${ }^{4}$, LGBTQ +, Queer, refugiados, palestinos, entre outras categorias. O

\footnotetext{
${ }^{3}$ Segundo, Reinhardt oselleck (2012, p. 234): “A história parece estar disponível sob dois pontos de vista - o do agente, que dispõe sobre a história que faz, e o do historiador, que sobre ela dispõe quando a escreve. Vista dessa forma, a liberdade de decisão de ambos parece não ter limites. Os homens determinam o campo em que a disposição da história é livre".

${ }^{4}$ Segundo Elias Ferreira Veras e Joana Maria Pedro (2014, p. 92): “Utilizamos a palavra 'homossexualidades', no plural, para designar as experiências de gays, lésbicas, travestis e transexuais. Contudo, reconhecemos às críticas dirigidas a este termo, assim como sua tendência à generalização que esconde a multiplicidade das experiências e as transformações históricas que marcam a trajetória dos sujeitos. Na perspectiva empregada nesse texto, os sujeitos se constituem atravessados pela pluralidade e multiplicidade dos discursos produzidos pelos dispositivos de poder e os processos de subjetivação historicamente contingentes. Assim, longe de sugerir qualquer ideia de essencialidade e generalidade, o termo 'homossexualidades', conforme o entendemos, aponta justamente para a pluralidade das práticas culturais, afetivas e sexuais, em constante transformação.". "Sem dúvida, a invisibilidade das homossexualidades nos estudos históricos não se justifica pela ausência de fontes. Afinal, as fontes não são elas mesmas produto do processo interpretativo, inventivo da operação historiográfica, resultantes da seleção e classificação feitas pelos/as historiadores/as? Tampouco representam uma aversão dos/as historiadores/as às novas temáticas - há muito os 'marginais', os 'vencidos', os 'excluídos', os 'silenciados' povoam os livros de história - ou mesmo ao tema da sexualidade” (p. 94).

Ronaldo Vainfas, (2002, p. 92) acerca da história de Benedetta Carlini de Vellano, abadessa do convento teatino de Pescia, início do século XVII, lésbica. Segundo Vainfas (2002), relata que o escândalo que se passava no
} 
Rev. Interd. em Cult.e Soc. (RICS), São Luís, v. 7, n. 1, p. 56- 79, jan./jun. 2021

silêncio é uma leitura de mundo, a mudez da boca tem sido a cegueira dos olhos. Como falar daquilo que não vemos, e se não vemos, o que temos a dizer? Para Michelle Perrot (2001, p. 239): "num mundo hostil, somente os grandes revoltados, ou os grandes condenados, ousam falar. Os outros, a massa dos reclusos, enterram-se no silêncio: quando libertados, só têm uma obsessão: fazer conhecer o passado, para serem 'aceitos'".

$\mathrm{Na}$ física quântica, área do conhecimento por vezes ignorada no mundo acadêmico, científico, sobretudo na história, de novo o silêncio acerca desta área do conhecimento se interpõe por não se conhecer suas premissas e aplicações. Quem enxerga é a cultura, os olhos são tão somente lentes que, crivadas por nossos referenciais de mundo, são capazes de, ao verem algo, não enxergar aquilo que Bakhtin definiu enquanto (2017, p. 27): "a posição do experimentador na teoria quântica. A presença dessa posição ativa muda a sua situação e, por conseguinte, os resultados do experimento". Segundo David Deutsch (1992), o cérebro é um computador quântico mais eficiente do que um computador digital.

O que faz do silêncio um silêncio? Como dito, o silêncio é a capacidade de não dizer algo, de ocultar, de não compreensão, uma mera limitação interpretativa sobre acontecimentos ou a simbiose de todos esses elementos? Por que as sociedades humanas apostam em olhar determinados aspectos e não outros? Falta de informações, capacidades analíticas limitadas, ou ainda, a forma como a dita realidade material, palpável, objetiva foi processada pelas culturas, transformada em códigos educacionais formais e não formais de uma maneira tão irretorquível a tal ponto que se condensou sob a forma de verdade? A verdade foi preconizada e ainda é alicerçada nos ditames estabelecidos pelos cinco sentidos humanos: visão, audição, tato, olfato e paladar.

Se a cultura é quem enxerga e não as retinas, são apenas as lentes de captação das imagens, como a cultura processa uma informação a tal ponto de não enxergar aquilo que é visto? Todorov (1993) nos conta que quando os espanhóis se preparavam para invadir a América, os astecas, obnubilados pela mitologia do retorno do seu deus Huitzilopochtli, em que figurava a inevitável catástrofe sobre a sociedade quando tal entidade retornasse do oriente para o ocidente, estando à beira da praia e mesmo percebendo que algo se aproximava

convento veio à tona com o depoimento da Freira Benedetta Crivelli, acompanhante especial da abadessa, mulher semianalfabeta e ingênua que, arguida pelos núncios, informou que Benedetta Carlini, em alguns de seus transes, encarnava o anjo Splentidello e começava a falar com voz grossa, beijando-lhe o pescoço, tocando os seus seios e prometendo-lhe felicidade em voz celestial. O depoimento de Crivelli desmascarou a fama mística de Benedetta Carlini - e por meio dele fica-se sabendo muito sobre como as mulheres usavam eroticamente o corpo naquele tempo.

Para conhecimento mais aprofundado sobre homoerotismo masculino, ver os trabalhos do historiador Luiz Mott, um dos pioneiros nessa temática. 
Rev. Interd. em Cult. e Soc. (RICS), São Luís, v. 7, n. 1, p. 56- 79, jan./jun. 2021

e se avolumava na linha do horizonte - as caravelas espanholas -, não processaram tal informação, não possuíam um referente para tal imagem. Quando os espanhóis desembarcaram em seus cavalos, tais animais não existiam no novíssimo continente, com suas roupas, barbas, feridas no rosto (escorbuto, falta de vitamina C), os astecas acreditavam se tratar do retorno de seu deus com suas pragas, por isso não ofereceram resistência à princípio e levaram muito tempo para se aperceberem que aquela cobiça pelo metal amarelo (ouro), não se tratava de uma entidade espiritual. Milhares desse povo foram mortos por vírus trazidos pelos europeus, pelos estupros, doenças venéreas e pelas guerras.

Os sentidos são consubstanciados pela fala, por códigos, estruturas de pensamentos, comportamentos, ritos, hábitos, gestos, posturas, crenças, emoldurando o que se entende enquanto cultura: conjunto de relações expoentes sobre como as pessoas, sociedades agem, se comportam, enxergam o mundo e se enxergam, veem o mundo e se veem, interpretam a realidade, encetam práticas sociais, e, como diria François Laplantine (2000, p. 120), “a cultura por sua vez não é nada mais que o próprio social, mas considerado dessa vez sob o ângulo dos caracteres distintivos que apresentam os individuais dos membros desse grupo, bem como suas produções originais (artesanais, artísticas, religiosas, etc.)".

Sob este prisma, os silêncios na e da história tanto podem ser ações, quanto omissões, que em última instância, são ações reificadas. Se a cultura direciona os olhares, o que vemos e/ou retemos quando enxergamos um fenômeno social ou queremos que os outros também assim o vejam? Há um deslocamento de uma simples omissão para uma preposição, um desejo, uma potência de um determinado grupo quando se apropria de uma história transformando-a em narrativa. O passado nem sempre é confortável, ainda que os mortos falem, fingimos não os escutar, como se tivessem deixado de existir, nós falamos por eles, damos vozes a eles, pois, como bem enfatizou Mikhail Bakhtin (2017, p. 59): "a alma nos fala livremente de sua imortalidade, porém não podemos prová-la”.

O que é a lembrança e o que constitui uma lembrança? Com essa pergunta Paul Ricoeur $^{5}$ (2008) coloca um axioma, nos moldes de Bergson ${ }^{6}$ (1999), ao se aproximar da

\footnotetext{
5 “Já não se trata de uma polaridade suscetível de ser abarcada por um conceito genérico como o de memória, mesmo desdobrando entre a simples presença da lembrança - a mnêmê dos gregos - é a recordação, a recollection - a anamnesis dos gregos. A questão embaraçosa é a seguinte: é a lembrança uma espécie de imagem, e, em caso afirmativo, qual? E, se, por uma análise eidética apropriada, se verificasse ser possível dar conta da diferença essencial entre imagem e lembrança, como explicar seu entrelaçamento, e mesmo a confusão entre ambas, não só ao nível da linguagem, mas no plano da experiência viva: não falamos de lembrançaimagem, e até da lembrança como de uma imagem que fazemos do passado? (RICOEUR, 2008, p. 61).
} 
Rev. Interd. em Cult. e Soc. (RICS), São Luís, v. 7, n. 1, p. 56- 79, jan./jun. 2021

ISSN eletrônico: 2447-6498

neurociência. Ambos defletem que o ato da lembrança, além de não espontânea, é inicialmente e em algum nível, uma seleção, consciente ou não. E de novo se interpõe a questão do olhar, crivado pelas culturas. $\mathrm{O}$ que fazem as culturas ao se direcionarem afetivamente às lembranças?

Do que lembramos quando recordamos de algo? A memória, que para Halbwachs (1990), possui dois níveis (a individual e a coletiva), estabelecendo uma comutação entre elas, retém a potência do que cognominamos enquanto experiência, e esta, enquanto potência, por vezes se coloca na condição de existência. Sendo assim, o silêncio sobre qualquer coisa, e nisto implica a história, quer individual, quer coletiva, é um domínio sobre as experiências que serão ocultadas.

Para Borralho (2020a, p. 1):

A latência das imagens se inicia com o nascimento, ainda que não haja clareza e nem conduta moral para inundar o que serão as lembranças puras. Tudo, no entanto, começa a ser registrado. O corpo absorve as imagens, matéria da vida. As lembranças puras sofrem inflexões das lembrançasimagens até se formarem percepções, propriamente ditas, já transformadas em representações, sentidos, como diria Bergson. O que permanece são as percepções, não mais as imagens puras. $\mathrm{O}$ corpo capta as imagens, mas o cérebro as processa. Tudo passa a ser fremido pela relação presençaausência. A cada afecção que interpretamos como ausência, é iniciado um processo inconsciente de busca por algo que supostamente possa preencher o vazio, ainda que inominável, ainda que não prefigurado. As dores, construções nomotéticas das memórias já elaboradas, editadas pela percepção, passam a se relacionar com o tempo distinguindo o ontem, passado; hoje, presente; e o amanhã, futuro, ainda que só exista o agora. É a dor da ausência que transforma o passado numa porta sem saída, pois só será passado, deixando de ser presente, exatamente quando a porta estiver aberta e deixar de ser presentificado tal passado. Basta uma imagem captada pelo corpo, ainda pura, depois transformada em lembrança por um ato simbolizado pelos sentidos enquanto referencial, para se constituir uma memória monumental. A vida, então, passa a ser o sentido da reatualização daquela lembrança ou do desejo de reificá-la. Se o presente não for prenhe de seu sentido, então, a porta do passado continuará aberta, intermitentemente.

Se nossas experiências em parte constituem memórias, que por sua vez, são determinantes no processo de aprendizagem, afinal, só é possível aprender com uma base de informações já constituídas e esquecendo parte do que se sabe, o que se aprende quando se está aprendendo? Indagando de outra maneira: o que constitui a aprendizagem, quais são seus

\footnotetext{
${ }^{6}$ Para Henri Bergson (1999, p. 162), toda imagem é produzida pelo corpo, no universo. "Equivale dizer que meu presente consiste na consciência que tenho de meu corpo. Estendido no espaço, meu corpo experimenta sensações e ao mesmo tempo executa movimentos".
} 
Rev. Interd. em Cult. e Soc. (RICS), São Luís, v. 7, n. 1, p. 56- 79, jan./jun. 2021

ISSN eletrônico: 2447-6498

fundamentos, suas implicações, para onde está se direcionando a partir de uma base de informações já constituídas? Se as informações são memórias agrupadas, o papel da ciência e da educação não seriam o de crítica quanto ao que constituem as informações transformadas em memória? A ciência ${ }^{7}$, enquanto discurso e prática, retroalimentada pela cultura, é um lócus operante da educação enquanto projeto normalizador dos comportamentos, crenças e ações e tais elementos fornecem chaves de leitura sobre os fenômenos físicos e sociais.

Borralho (2017), ao estudar Hameroff, afirma que no nível subneural ocorrem os processamentos de informações, isto quer dizer que as células possuem uma delicada estrutura formada por microtúbulos de proteína, formando um citoesqueleto. Este mecanismo possui uma função cognitiva, ligada à memória ${ }^{8}$.

Segundo Borralho (2017, p. 51):

Cientistas afirmam que o nosso organismo, apesar de interconectado funcionalmente, cada célula, partícula, glândula, opera por mecanismos de autonomia relativa porque possui um conjunto de memórias que vão se formando com os anos de um determinado indivíduo. Cada célula e glândula têm um arcabouço de operações químicas ligado às suas memórias. Cada célula possui um conjunto de microtúbulos que recebe a partir do sistema de encaixe, uma enzima ou proteína liberada pelo sistema nervoso. Como essas enzimas ou proteínas sabem exatamente qual a sensação liberada pelo sistema nervoso? Cada sensação no nosso organismo está relacionada ao conjunto dos peptídeos que existem no nosso sistema biológico, isto quer dizer que para cada sensação, desejo ou fantasia produzida internamente, existe uma combinação diferente que desencadeia reações químicas. Por exemplo: os sentimentos de amor, ódio, raiva, alegria, tristeza etc. estão relacionados à memória das células e glândulas que buscam conotativo para essas sensações provocadas pela conexão com os peptídeos. Quando uma célula se segmenta formando uma outra célula exatamente igual à anterior, a quantidade de microtúbulos existentes nesta nova célula está ligada aos anos de vida que o indivíduo produziu em forma de sensações, da vida que construiu, ou seja, a quantidade de receptores para coisas positivas, boas, alegres que uma célula terá será menor se ao longo da vida bombardeamos nosso organismo com sensações ruins, tristes e derrotistas, desanimadoras, pois como dito, no sistema nervoso, os neurônios constroem teias de relações de longo, curto ou médio prazo. Este é o modelo de Frölich.

\footnotetext{
${ }^{7}$ Para Boaventura Sousa Santos (2001, p. 223): A universidade constitui-se em sede privilegiada e unificada de um saber privilegiado e unificado dos saberes produzidos pelas três racionalidades da modernidade: a racionalidade cognitiva-instrumental das ciências, a racionalidade moral-prática do direito e da ética e a racionalidade estético-expressiva das artes e da literatura. As ciências da natureza apropriaram a racionalidade cognitivo-instrumental e as humanidades distribuíram-se pelas outras duas racionalidades. As ciências sociais estiveram, desde o início, fraturadas entre a racionalidade cognitivo-instrumental e a racionalidade moral-prática. A ideia da unidade do saber universitário foi sendo progressivamente substituída pela da hegemonia da racionalidade cognitivo-instrumental e, portanto, das ciências da natureza. A crise deste paradigma não pode deixar de acarretar a crise da ideia de universidade moderna.

${ }^{8}$ Para aprofundamento destas questões, ver, entre outros, MARTINS; VIZZOTTO; LIBRELLOTO (2011).
} 
Rev. Interd. em Cult. e Soc. (RICS), São Luís, v. 7, n. 1, p. 56- 79, jan./jun. 2021

ISSN eletrônico: 2447-6498

Se o conjunto de informações existentes nos microtúbulos são lidos enquanto sensações, que, por sua vez, são interpretados pelo olhar, uma variação da cultura, silenciar sobre um fato, ocultá-lo, ainda que inconscientemente, visto que os indivíduos solitariamente possuem os mecanismos e códigos sociais de aceitação, reprovação, é sempre uma mediação com o outro, o que se entende enquanto corpo social não constitui um jogo de poder, logo, de dominação?

As correntes históricas ${ }^{9}$, fruto das relações de poder dentro do campo historiográfico, por vezes são nossas vozes, direcionam o olhar para onde devemos pensar os rumos das pesquisas. Servindo do mesmo princípio do olho do observador, quem enxerga aquilo que depois em história será estudado? São os historiadores, primeiramente de forma individualizada ou por meio de uma teoria, que se colocam como um prisma a ser percebido?

A história enquanto ciência é uma operação, herdeira do século XIX e de sua concepção nascente naquela centúria, quando absorveu e lutou para ter seu status de "conhecimento válido, científico". O que estava em jogo naquele momento era a forma como a noção de verdade científica, preconizada pelos ideais de veracidade, logicidade, experimentação, empirismo, herdeiras dos pensamentos de Descartes e Bacon, em oposição ao pensamento considerado atrasado do mundo antigo, interpretado enquanto mítico, mágico, a partir da ascensão do capital, passou cada vez mais a assumir caracteres burgueses ${ }^{10}$, interpretados enquanto práticos, reconhecíveis, ganhando o estatuto de verdade. A metafísica filosófica, ainda que racional e lógica, não fazia mais frente ao avanço da técnica, da aceleração do capital que demandava conhecimentos operacionais sob a alcunha de progresso, da alta velocidade da vida, impulsionada pela máquina a vapor, pelas fumaças das chaminés, pelo sentimento ideológico de se sentir pertencente ao mundo revolucionário, mutante das paisagens bucólicas medievais. A verdade passava cada vez mais a ser a imediata, não mais a especulativa, era aquela que conseguia atender aos desejos e sentidos do novo ideal de vida,

\footnotetext{
${ }^{9}$ Segundo Reinhardt Koselleck (2012, p. 235): "O conceito atual de história, com seus numerosos campos semânticos que em parte se excluem logicamente, só veio a ser formado a partir do final do século XVIII. Resulta de longas reflexões teóricas do iluminismo. Antes existia, por exemplo, a história que Deus realizava com a humanidade, mas não havia uma história que tivesse como sujeito a humanidade, ou uma história que pudesse ser imaginada como sujeito de si própria. Havia histórias no plural, histórias de todo o tipo, que aconteciam e podiam servir de exemplos para o ensino moral e teológico, para o direito e a filosofia".

${ }^{10}$ Para Walter Benjamin (2011, p. 55): "Quem acredita que o homem comunica sua essência espiritual através dos nomes, não pode, por sua vez, aceitar que seja a sua essência espiritual que ele comunica, por isso não se dá através de nome de coisas, isto é, não se dá através das palavras com as quais ele designa uma coisa. Por sua vez, pode aceitar apenas que comunica alguma coisa a outros homens, pois isso se dá através da palavra com a qual eu designo uma coisa. Tal visão é a concepção burguesa da linguagem, cuja inconsistência e vacuidade devem resultar cada vez mais claras, a partir das reflexões que faremos a seguir. Essa visão afirma que o meio $\{$ mittel $\}$ da comunicação é a palavra; seu objeto, a coisa; seu destinatário, um ser humano".
} 
Rev. Interd. em Cult.e Soc. (RICS), São Luís, v. 7, n. 1, p. 56- 79, jan./jun. 2021

não mais transcendente, agora, imanente. $\mathrm{O}$ conhecimento, ou o tipo de conhecimento que pudesse corresponder aos desejos dos avanços tecnológicos, ganhou a primazia de ser reconhecido enquanto científico, pois seu postulado supostamente era verificado nas lentes dos microscópios ou nas entabulações das equações físicas e matemáticas. Desta feita, nascia a hierarquização entre as ciências. Estas, são classificadas de naturais, cujos postulados tinham respostas práticas, objetivas e "verdadeiras"; e de humanas, sociais, cujos resultados de seus problemas não eram exatos, logo, nunca se repetiam, portanto, de natureza especulativa, subjetiva. Para Mikhail Bakhtin (2017, p. 59): "o objeto das ciências humanas é o ser expressivo e falante. Esse ser nunca coincide consigo mesmo e por isso é inesgotável em seu sentido e significado".

Esses cientistas não conseguiam enxergar que, por trás de tais premissas, havia pelo menos dois axiomas. No primeiro, as noções balizadoras da verdade científica subjazem aos interesses do capital, quer dizer, a verdade científica era tudo aquilo que atendia às demandas da lógica da aceleração material, do progresso, capaz inclusive de emular a "felicidade" e a "paz". No segundo, que é mais complexo, emblemático, não se conseguia enxergar que, quando se formula uma hipótese científica, os signos por detrás de tal hipótese, necessariamente só são entendidos enquanto científicos, não porque o objeto estudado assim o seja, e sim, porque as categorias de entendimento sobre o objeto analisado são, antes de qualquer coisa, culturais, "subjetivas". Os objetos de análise não se autodefinem, não são autorreferentes, recebem atribuições, referências. Isto não quer dizer que existe um impasse, uma impossibilidade de significação sobre qualquer coisa, que estamos imersos numa ataraxia, numa rua sem saída, pois qualquer significação é arbitrária, fruto da linguagem ${ }^{11}$, e sim, de entendermos como nascem as atribuições, quais são os signos por detrás dos referentes, os interesses, as motivações, pois como bem Terry Eagleton (2021, p. 86): "os signos só têm sentido em relação a outros signos, não existe um grande signo final, assim como não existe uma grande pessoa ou um número final". Não se trata de não podermos atribuir significado algum sobre qualquer coisa, mas de compreendermos quais os signos por detrás de qualquer significação.

\footnotetext{
${ }^{11}$ Segundo Walter Benjamin (2011, p. 72): Isso permite definir uma outra oposição que atravessa todo o campo da linguagem que apresenta relações importantes com a oposição já assinalada entre a linguagem em sentido estrito e o signo, com o qual, é claro, a linguagem não necessariamente coincide. Pois de todo o modo a linguagem nunca é somente comunicação do comunicável, mas é, ao mesmo tempo, símbolo do nãocomunicável. Esse lado simbólico da linguagem está ligado à sua relação com o signo, e estende-se também, por exemplo, em certos aspectos, ao nome e ao julgamento. Estes têm não apenas uma função comunicante, mas também, com toda probabilidade, uma função simbólica em estreita conexão com esta - à qual não se aludiu aqui, pelo menos não de modo explícito.
} 
Rev. Interd. em Cult. e Soc. (RICS), São Luís, v. 7, n. 1, p. 56- 79, jan./jun. 2021

ISSN eletrônico: 2447-6498

Para Schlegel (2018, p. 85):

O pensador não chega à investigação científica em estado inocente e incólume. Ele se encontra contagiado pela influência de experiências equivocadas, trazendo consigo preconceitos os quais podem dar orientação inteiramente falsa para suas investigações, até mesmo no campo da abstração pura. Mesmo possuindo o mais honesto fervor, não se encontra em suas mãos o poder de renunciar a esses poderosos preconceitos de uma vez, pois, ele já deveria ter compreendido a verdade pura para notar o fundamento do erro, e saber quão equivocado é seu método.

Isso vem ocorrendo desde a emergência da modernidade no campo científico, acadêmico, também acontece no cultural, simbólico, político, econômico, social, religioso, educacional. Se o capital, lastreado pela técnica, foi a baliza incentivadora para se designar as noções de avanço, progresso, modernidade, lógica, ciência, as sociedades que, do ponto de vista da acumulação do capital europeu não lhe eram paralelas, foram consideradas atrasadas, subculturas, até mesmo incivilizadas. Ora, se a história carregava o estandarte da classificação de como deveriam ser interpretadas as sociedades, as civilizações, e a referência era o mundo europeu, todas as demais não possuíam "história", leia-se, cultura.

Segundo Boaventura de Sousa Santos (2000, p. 50):

O paradigma da modernidade é um projecto ambicioso e revolucionário, mas é também um projecto com contradições internas. Por um lado, a envergadura das suas propostas abre um vasto horizonte à inovação social e cultural; por outro, a complexidade dos seus elementos constitutivos torna praticamente impossível evitar que o cumprimento das promessas seja nuns casos excessivo e noutros insuficiente. Tanto nos excessos como os défices estão inscritos na matriz paradigmática. O paradigma da modernidade pretende um desenvolvimento harmonioso e recíproco do pilar da regulação e do pilar da emancipação, e pretende também que esse desenvolvimento se traduza indefectivelmente pela completa racionalização da vida coletiva e individual.

Se quem enxergou foi a cultura, as sociedades, sobretudo as asiáticas e as africanas, foram vistas como subalternas, e isso implica suas histórias, tradições e pensamentos. Chegou-se a formular que o continente africano sequer elaborou um pensamento filosóficocientífico, e que as filosofias indianas e chinesas não poderiam ser consideradas enquanto tais.

Para Achille Mbembe (2014, p. 99):

No horizonte filosófico do nosso tempo, o termo África não significa nada mais senão a maneira como se verbaliza a questão política da dissecação do vivo; a maneira de interromper politicamente a duração, a secura e as vicissitudes da vida ou, ainda, as formas visíveis, porém opacas e cegas, que a morte acabou por cobrir no comércio contemporâneo entre os vivos.

Por detrás da palavra - o que esta diz ou esconde, ou, ainda, que não sabe dizer, e até o que diz sem ainda por ser ouvida - dirigem-se assim a uma 
certa figura do nosso mundo, do seu corpo e do seu espírito, algumas das mais imundas imagens do presente, o escândalo da humanidade, o testemunho vivo, inquestionavelmente perturbador da violência do nosso mundo, e da desigualdade que é seu principal motor, que impõe ao pensamento do mundo e do devir as exigências indubitavelmente mais urgentes e mais radicais, a começar pela da responsabilidade e da justiça. A palavra África ocupa o lugar de uma negação fundamental dos dois termos.

Somente a reversão dessa lógica do pensamento pode propiciar a que o próprio pensamento redirecione a forma como enxergamos a cultura, o mundo. A crise no modelo societal instalou a dúvida. Esta encetou uma outra análise, sucedida por outra reflexão crítica e por mudança paradigmática. A crítica ao modelo societal lógico dedutivo possibilitou novas bases reflexivas, criticando a própria matriz do pensamento filosófico - lógico ocidental, ainda que usando suas próprias premissas. O pensamento repensa sua trajetória e tenta se libertar das amarras que ele mesmo se entranhou. Para Frantz Fanon (2008, p. 34): "todo povo colonizado - isto é, todo povo no seio do qual nasceu um complexo de inferioridade devido ao sepultamento de sua originalidade cultural — toma posição diante da linguagem da nação civilizadora, isto é, da cultura metropolitana".

Uma dessas aporias é o pensamento teórico decolonial. O decolonialismo é a forma como enxergamos as matizes do colonialismo em todas as esferas, entre eles, como se interpuseram os silêncios na história, no caso das sociedades não europeias e até de algumas sociedades europeias, uma vez que uma visão de mundo, uma lente foi usada para interpretar um modelo de vida ideal. Para Flávio Lazzarin (2015), uma das saídas, no caso do Brasil, para reversão do colonialismo ${ }^{12}$, é a antropofagia ${ }^{13}$.

Segundo Mignolo (2003, p.136-137):

A pós-colonialidade é tanto um discurso crítico que traz para o primeiro plano o lado colonial do sistema mundial moderno e a colonialidade do poder embutida na própria modernidade, quanto um discurso que altera a proporção entre locais geoistóricos (ou histórias locais) e a produção de

\footnotetext{
12 Segundo Flávio Lazzarin (2015, p. 3): "Podemos entender colonização a partir de processos diferentes. O primeiro é constituído pela invenção, encobrimento, descoberta, conquista e submissão material e espiritual destas terras e povos, que os europeus chamaram de América. Processo este, que perdura até os nossos dias, revelado nas relações de dominação entre capital-estado versus povos originários, comunidades negras e comunidades camponesas tradicionais. Nestas últimas décadas, indígenas, quilombolas e as inúmeras "vias campesinas" se reinventam politicamente, com insurgências em que identidades culturais e territorialidades são conjugadas em termos de autonomia e de tendencial alternativa ao estado e à civilização capitalista".

${ }^{13}$ Para Flávio Lazzarin (2015, p. 3): "O perdurar do processo colonizador aparece também no enfrentamento descolonizador no âmbito da literatura e das artes plásticas. Lembramos, assim, a Semana de Arte Moderna de 1922, quando nasce o paradigma da antropofagia, em que artistas e intelectuais brasileiros se contrapõem criticamente à dependência dos valores transmitidos pelos centros hegemônicos para transgredi-los, marcando sua diferença e originalidade. Contraposição esta, também com relação aos artistas e intelectuais que estariam no Brasil somente com as partes menos nobres da sua anatomia e que, sentados à beira do oceano Atlântico, teriam as suas cabeças rendidas ao sistema eurocêntrico".
} 
conhecimentos. O reordenamento da geopolítica do conhecimento manifesta-se em duas direções diferentes mas complementares: 1. A crítica da subalternização na perspectiva dos estudos subalternos; 2. A emergência do pensamento liminar como uma nova modalidade epistemológica na interseção da tradição ocidental e a diversidade das categorias suprimidas sob o ocidentalismo; o orientalismo (como objetificação do lócus do enunciado enquanto 'alteridade') e estudos de área (como objetificação do "Terceiro Mundo", enquanto produtor de culturas, mas não de saber).

No entanto, como pensar diferente se há uma colonização nas formas de pensamento? O primeiro passo é reconhecer as categorias de pensamento, as epistemologias, suas origens, matizes, filiações, reverberações, extensões; o segundo, operar a desconstrução de tais nexos. Isso exige não apenas uma reflexão crítica, como também uma ação biopolítica. Decolonizar o pensamento e acionar mecanismos de mudança de paradigmas é tomar lugar no centro das decisões políticas, inverter a lógica do raciocínio, assumir uma atitude ainda mais reflexiva e autocrítica, rever postulados, modelos correlacionais, revisar o passado, reescrever a história, assumir responsabilidades, erros, deslocar paisagens e georreferencias, colocar-se como protagonista das ações sociais e não mais, enquanto caudatários do processo, ouvir os silêncios e perceber como foram construídos.

Tomando novamente Mignolo (2013, p. 165-6):

Ao insistir nas ligações entre o lugar da teorização (ser de, vir de e estar em) e o lócus de enunciação, estou insistindo em que os loci de enunciação não são dados, mas encenados. Não estou supondo que só pessoas originárias de tal ou qual lugar poderiam fazer. Permitam-me insistir em que não estou vazando o argumento em termos deterministas, mas no campo aberto das possibilidades lógicas, das circunstâncias históricas e das sensibilidades individuais. Estou sugerindo que aqueles para quem as heranças coloniais são reais (ou seja, aqueles a quem elas prejudicam) são mais inclinados (lógica, histórica e emocionalmente) que outros a teorizar o passado em termos de colonialidade. Também sugiro que a teorização pós-colonial relocaliza as fronteiras entre o conhecimento, o conhecido e o sujeito conhecedor (razão pela qual enfatizei as cumplicidades das teorias póscoloniais com as "minorias").

Tal postura exige igualmente o refazer das trajetórias históricas admitindo que o foi construído é antes de qualquer coisa uma ação consciente, uma opção de dominação, estratégia de subjugação, construção de sentidos de passado, de interpretação e narrativas. Não se trata de relativismo ou mesmo de jogos semânticos plurissignativos, estabelecendo, no plano da linguagem, uma mera disputa hermenêutica, como se esta pairasse acima das condições objetivas, tendo conotação em si mesma, sem referentes, nexos sociais, como se a linguagem fosse autômata, plenipotente, onipresente e, portanto, como se dentro de seus ritos tivesse autorreferência, vida própria e comandasse as ações práticas e objetivas da vida. Essa 
Rev. Interd. em Cult. e Soc. (RICS), São Luís, v. 7, n. 1, p. 56- 79, jan./jun. 2021

ISSN eletrônico: 2447-6498

dicotomia, historicamente datada de distinção entre doxa e epistheme, mundo das ideias e mundo real, teoria e prática, foi um dos mecanismos de dominação simbólica e política, entre pensamento reflexivo, filosófico e atitudes cotidianas de sociedades ritualísticas, consideradas sem pensamento elaborado, simplórias, atrasadas, míticas. Sociedades essas encaradas como necessitadas de instrumentalização teórica, oriunda de lugares de uma suposta elaboração intelectual, leia-se, fornecedoras de uma epistemologia modelo, referencial.

Foi assim que até mesmo a Europa, promulgadora dessa pletora condição de superioridade cultural, na ânsia da superação de seu passado mítico, símbolo a ser ultrapassado, processou um lógus fracionado, segmentado, compartimentalizado, atomizado. As formas de sentir, intuir, saber e conhecer por outras vias, passaram a ser vistas como afecções, sentimentalismos, páthos, inferiores em comparação a novo lógus, fruto do distanciamento, da distinção entre poesia ${ }^{14}$ e filosofia, criando a separação entre holismo ${ }^{15}$ e especialização.

O pensamento holístico, que havia dado origem à própria filosofia, aos poucos foi sendo conotado enquanto algo a ser superado, estabelecendo pares supostamente antitéticos como sensibilidade e pragmatismo, intuição e dedução, sensitismo e empiria, improvisação e

14 "NUNES, Benedito (2011), em Hermenêutica e poesia, defende que a separação completa dos territórios terá sido, segundo Macherey, um evento histórico no final do século XVIII, quando o termo literatura começou a ser utilizado em sua significação moderna ou, como diria Michel Foucault (1999), quando a literatura ascende como literatura, concomitantemente à descoberta da linguagem como algo essencial ou substancial. No momento em que Goethe usa a expressão "poesia universal" para referendar Schlegel, estaria começando o confronto que as constitui como essencialidades autônomas, envolvidas no campo que define uma e outra e fixa seus limites. Giorgio Agamben esclarece e perscruta as sendas do processo de criação artística entre a relação que envolve a poética e sua imbricada conjunção com a filosofia, sem olvidar de como a crítica no mundo ocidental construiu seu arcabouço a partir da linguagem, do texto como elemento semântico e sintagmático de explicação do mundo, à medida em que a razão instrumental ora recorria à poesia, ora se distanciava dela, enquanto mecanismo compungido de expiação do sentimento de descoberta do cosmos", segundo Borralho (2020-b, p. 328).

Segundo Schlegel (2018, p. 147): "o pensamento mítico era de que a poesia era um dom e uma revelação dos deuses, e de que o poeta era um sacerdote sagrado e porta-voz dos mesmos, permaneceu por todas as épocas uma crença popular grega. A ela se relaciona as doutrinas de Platão, e provavelmente também as de Demócrito sobre o entusiasmo musical e a divindade da arte. Em geral, a exposição popular (exotérica da filosofia grega) possuía um colorido mítico".

Segundo Walter Benjamin (2017, p. 38): “o poeta vivia o verdadeiro. Dessa maneira, o povo era conhecido por ele. Na ordem divina, entretanto, existe, como se verá uma identidade interna, peculiar das figuras. Essa identidade já se encontrava sugerida na imagem do espaço e, por exemplo, na determinação da superfície pelo ornamento. Porém, alçada a instância dominante de uma ordem, ela provoca uma objetivação do vivente".

Foucault, em Ditos e Escritos (1999) e em Linguagem e Literatura (apud MACHADO, 2000), afirma que não havia literatura na Antiguidade, notadamente entre os gregos e latinos, e a apropriação dos que eles faziam enquanto literatura é uma construção moderna, já que, para Foucault, o nascimento da literatura tal como a concebemos está relacionado à ideia de loucura, da morte de Deus, da própria modernidade. (FOUCAULT, 1999, 2000).

15 "Termo inventado, em 1926, por J.C Smuts para designar a tendência do universo para construir unidades que formam um todo e de complexidade crescente (Cuvillier, 1979, p, 87). Se observarmos o processo de evolução, mesmo até nossos dias, é difícil não notar seu fato mais marcante: seu crescimento holístico", segundo Pierre Weill (1987, p. 85). 
Rev. Interd. em Cult. e Soc. (RICS), São Luís, v. 7, n. 1, p. 56- 79, jan./jun. 2021

método, acaso e previsibilidade, improvisação e planejamento, circunstancialidade e objetividade, natural e artificial, natureza e homem-mulher, estômago e cérebro, espirito e corpo $^{16}$, sentimento e pensamento, fábulas e histórias, mito e ciência, magia e epistemologia, uno e múltiplo, conectividade e cinco sentidos, sabedoria e inteligência, lógus e razão.

O etnocentrismo é um dos pilares deste processo. Imaginarmo-nos como o centro do Universo, consequentemente tudo o que é derivado disso - nossos referenciais -, funciona como duplo vórtice: nos impede de enxergar o que existe para além de nossos sentidos, ao mesmo passo que fixa o status quo. Resultado: avançamos muito pouco acerca do desvelamento sobre quem somos, isso sem olvidar dos instrumentos de controle sobre o que é saber, como a educação.

O que Durkheim (1983) alertava era que o indivíduo de fato existe, mas dentro de uma margem muito pequena de circunstância: indivíduo é, na verdade, o que fazemos com a somatória de informações que nos cercam, o resto é sujeito-coletivo, ou seja, a rede que nos molda desde o nascimento abarcando uma conjugação de fatores e pessoas de que não nos damos conta: família, escola, bairro, ambiente de trabalho, universidade, lazer, etc.

As sociedades são uma ampliação macroscópica dos indivíduos. Indivíduo é uma constituição jurídica, cultural, social. Pessoas, ainda que perpassadas por essas noções, possuem elementos subjetivos, tangidas pelo social, mas não completamente atreladas a ele. As sociedades avançam porque as pessoas mudam, mas isso ocorre dentro de uma margem pequena de inflexão. Até mesmo as mudanças são controladas pelo grande capital, pela educação, ciência, em última instância, por uma cultura notabilizada, orquestrada. É uma simbiose a relação entre ciência, educação e cultura, estratagemas de poder. O silêncio ou os silêncios na história são antes de qualquer coisa o controle sobre a vida.

Se tomarmos $\operatorname{Marx}^{17}$ (2003) como premissa, antes desse filósofo, a teoria metafísica do espírito absoluto, que caminhava por sobre a humanidade, cujo sentido de interpretação da história foi impetrado por Hegel, e tomado como "uma verdade", um sentido que direcionava nossas forças e sentidos obnubilando a possibilidade de vermos o motor da história,

\footnotetext{
16 “Corpo e espaço, lembrando, no entanto, que aquele não apenas ocupa esse, porém o dirige e o ordena segundo sua vontade" (TUAN, 2012, p. 837).

17 Segundo Reinhard Koselleck (2012, p. 242): Sempre que pôde, Marx tentou desfazer todo conceito substancial de história, desmascará-lo como sujeito metafísico presente na linguagem de seus adversários. Suas obras histórico-teóricas não se deixam reduzir unicamente aos objetivos utópicos que lhe conquistaram repercussão mundial. Ao contrário, suas análises históricas se alimentam de uma diferença que distingue entre o agir humano e aquilo que efetivamente se realiza a longo prazo. Nessa distinção se fundamenta sua análise do capital e também sua crítica da ideologia, por exemplo, àqueles "ideólogos "que ridicularizou como "fabricantes da história".
} 
Rev. Interd. em Cult.e Soc. (RICS), São Luís, v. 7, n. 1, p. 56- 79, jan./jun. 2021

ISSN eletrônico: 2447-6498

impulsionado pelas forças dos trabalhadores e como a mão invisível da ideologia, impedia de enxergar a estrada à sua frente, como uma espécie de neblina.

Desde a insurgência do capital, vem se acelerando um conjunto de silêncios orquestrados. Uma das bandeiras do liberalismo dos séculos XVII e XVIII foi a propugnação das noções de liberdade do mercado e do indivíduo. Com o fim da ideia de salvação coletiva, medieval e a emergência do protestantismo calvinista, o foco burguês passou a ser o indivíduo, plenipotente em suas escolhas, crente num projeto moderno de civilização, desfocado de uma noção de interação social, e voltado agora para sua capacidade de lutar e construir projetos e da valorização de sua subjetividade - basta olhar a terceira fase do Renascimento na pintura: a fase dos autorretratos. Contratar um pintor para um autorretrato era não só ultrapassar o medo da vaidade do pecado, bem como acreditar na potência de que o "eu”, enquanto categoria, deveria ser estandardizado. Assim, um ideal burguês de indivíduo, paulatinamente, ganhava força consubstanciado numa ideia de liberdade de ação política e econômica, sem olvidar do crescimento do capitalismo pari passu a esse processo.

Para Eagleton (2021, p. 119):

Um dos traços mais distintivos do capitalismo é que ele nos compele a voltar a maioria de nossas energias criativas para questões de caráter utilitário: os meios de vida se tornam um fim. A vida se resume a deitar as bases materiais da subsistência. Por incrível que pareça, em pleno século XXI, a organização material da vida é tão relevante quanto na Idade da Pedra. O capital que poderia ser destinado a liberar as pessoas das energias do trabalho, que fosse em grau moderado, é dedicado em vez disso, à acumulação de mais capital.

Isso só demonstra o quanto o nosso olhar é enviesado pelos ditames do poder que opera a forma como uma classe se sobrepõe à outra, protegida por aparelhos como o direito, o estado, a propriedade. A outra forma de não percebermos as vozes dos silenciados passa exatamente pelo capital que educa pela cultura e a noção de que quem não foi capaz de capitalizar, não venceu o axioma estabelecido em discursos como o da publicidade.

Segundo Vilém Flusser (2011, p. 73):

A sociedade ocidental é tecido comunicativo muito específico. Não é caracterizada apenas pelos assuntos comunicados, mas sobretudo pelos métodos graças aos quais comunica. Grosso modo, o Ocidente elaborou dois tipos de diálogo, e quatro tipos de discursos. Os diálogos são circulares (exemplos: mesas redondas, parlamento), ou redes (exemplos: sistemas telefônicos, opinião pública). Os discursos são teatrais (exemplos: aulas, concertos), piramidais (exemplos: exércitos, igrejas, árvores (exemplos: ciências, artes) e, anfiteatrais (exemplo: rádio, impressa). A história ocidental pode ser vista enquanto jogo comunicativo que vai aplicando tais 
Rev. Interd. em Cult. e Soc. (RICS), São Luís, v. 7, n. 1, p. 56- 79, jan./jun. 2021

métodos de comunicação como estratégias. O propósito dessas estratégias todas é o de produzir e acumular informações novas.

A situação atual da sociedade ocidental é marcada pelo predomínio dos discursos sobre os diálogos. A queixa generalizada de "falta de comunicação" foi mal formulada. A solidão das massas, que é o fundamento de queixa, não é consequência da pobreza do tecido comunicativo. Pelo contrário: jamais os discursos ocidentais funcionaram tão bem quanto atualmente, e sobretudo jamais funcionaram tão bem a árvore da ciência e o anfiteatro das comunicações de massa.

A sociedade da experienciação se transformou na sociedade da decepção, ou seja, naquela cuja descoberta de seus desejos e potencialidades tornaram homens e mulheres reféns da busca pelo prazer e felicidade a todo custo, com uma grande incapacidade de lidar com suas frustrações.

A sociedade contemporânea consumista possui uma imensa incapacidade de enfrentar seus medos, angústias, desafios e temeridades. Recorre a todo e qualquer custo a aparatos, placebos, ferramentas que propiciem a fuga das dificuldades da realidade. É uma sociedade imediatista, impaciente, acelerada, descartante de tudo que julga descartável, inclusive pessoas.

Segundo Gilles Lipovetsky (2006, p. 26, 27):

Naturalmente, como tantos outros sentimentos, a decepção é uma experiência universalmente partilhada pelos homens. Enquanto ser de desejo cuja essência é negar o que é - Sartre dizia do homem que ele não é o que é e que é o que não é - o homem é um ser que espera e que, assim não pode escapar a experiência da decepção. Desejo e decepção andam lado a lado, a diferença entre expectativa e real, princípio e prazer e princípio da realidade, raramente é satisfeita. Mas se a decepção faz parte da condição humana, será necessário observar que a civilização moderna, individualista e democrática, lhe deu um peso e um relevo excepcionais, uma superfície psicológica e social sem precedentes históricos. Do século XIX ao século XX, os filósofos pessimistas (Schopenhauer, Cioran) negam a possibilidade da felicidade, $\mathrm{o}$ desejo e a existência não podem conduzir senão a uma infinita decepção.

A questão é que o capital propugnou e condicionou aos homens e mulheres o consumo como remédio e mediação da felicidade, logo, tudo se transforma em mercadoria quando a mercadoria não satisfaz a saciedade humana emerge a decepção, a frustração. Os limites do capital, enquanto variante promotora da felicidade, dão mostras desde meados do século XX, que não supriria nossas carências, ao contrário, aumentou a lógica da competitividade, da agressividade e, consequentemente, das frustrações, vide que ela é a promotora da pletora noção de vida feliz, como se a felicidade pudesse ser comprada numa gôndola de supermercado. 
Rev. Interd. em Cult.e Soc. (RICS), São Luís, v. 7, n. 1, p. 56- 79, jan./jun. 2021

O problema se torna ainda mais agudo quando o pusilânime conceito de cidadania entra em cena. O que é ser cidadão? Ser consumista das lógicas e das ofertas políticas do jogo democrático. Há a democratização das possibilidades, mas há também paralelamente a privatização dos meios, por isso as frustrações, depressões e angústias.

A definição moderna de democracia burguesa se assenta no fato de que nesta acepção o capital controla o aparato burocrático do estado na defesa dos seus interesses, da livre concorrência, das lógicas do mercado, e, sobretudo, nas ideologias de setores dominantes, que por extensão, dominam per si o próprio estado.

O conjunto e aparato jurídico, normatizador da sociedade de direito dentro da democracia burguesa, estão assentados em princípios burgueses, tais como a constituição (carta magna), código civil e penal, cujos valores expressam os anseios dos setores dominantes portadores de tal ideologia, entre elas: a noção de redução do estado, do controle midiático expressando valores do consumo, da defesa irrestrita da propriedade privada, mesmo quando as condições de aquisição de certas propriedades se dão de forma escusa (falsificação de documentação), privatização de setores estratégicos: educação, saúde, transporte, proteção aos setores produtivos do agrobusiness em detrimento da expulsão do homem do campo, entre outras tantas injustiças e anomalias sociais.

As formas de controle social, tais como: a educação competitiva em nome do capital, a propaganda democrática, que afirma ser o melhor modelo de representação política, olvidando os meneios de controle do aparato burocrático da justiça; o financiamento de campanha; a privatização dos espaços políticos em decorrência do engessamento da participação popular, dificultado pelo acesso às informações e pelas hierarquias; a burocracia e o controle da mídia; o caráter excludente das classes sociais afirmando haver, sim, a separação e a distinção entre os indivíduos, como se algumas fossem blindadas pela natureza e destinadas a serem privilegiadas; a cultura, alicerçada pelos valores morais, pela religião, pelo entretenimento. Todas essas questões têm funcionado como um processo retroalimentador (os valores criam a cultura, essa uma vez estabelecida, volta a retroalimentar os valores sociais), servindo de alicerce para uma miopia global, consubstanciando a ideia de que tudo se dá de forma natural e não há outra possibilidade de enxergá-las.

Desde a criação do Federal Reserve (23 de dezembro de 1913), um modelo de concentração e a forma da tomada de decisões sobre os rumos da economia global têm sido direcionados pelos países centrais capitalistas, sobretudo, a partir de suas agências surgidas postumamente: FMI, Banco Mundial e, no plano da política, por agências como ONU, 
Rev. Interd. em Cult. e Soc. (RICS), São Luís, v. 7, n. 1, p. 56- 79, jan./jun. 2021

OTAN, interferindo e intervindo na dinâmica socioeconômica política dos países, sempre em benefício dos mais ricos, passando pelo atraso da grande mídia quanto ao engendramento da economia global ao noticiar tardiamente a prisão de banqueiros na Finlândia, pelo envolvimento na fraude da crise econômica global, e a multa que a Standard \& Poor's obteve, por causa do recebimento de US\$ 1,37 bilhões, devido à fraude em garantias de créditos imobiliários (STANDART \& POOR'S...2015), constituem estratagemas de um mundo fragmentado.

Como mudar então os regimes políticos? Não alimentando os processos e mecanismos de sustentação de tais modelos, como: a ideia de que somente alguns nasceram para serem afortunados, baseada no princípio da livre concorrência, como se fosse ético e natural; questionando os princípios fundantes da democracia, tida como melhor modelo de representação; não problematizando os engendramentos, farsas e mentiras, sustentáculos dos regimes, como a justiça, a burocracia, a mídia; entendendo que todos estamos interligados, portanto, para o estabelecimento de um equilíbrio é necessária a redução brusca da desigualdade, a eliminação da injustiça que massacra negros, índios, quilombolas, pobres, refugiados, mulheres, crianças, idosos em vários lugares do mundo; lutando para que os recursos naturais sejam mantidos e aos quais todos tenham acesso, independentemente de suas condições sociais.

O colapso no sistema financeiro mundial e uma modificação do modelo econômico global são impedidos pela artificialização dos balanços contábeis, da farsa das bolsas de valores, da manutenção da paridade do dólar como moeda e padrão internacional das trocas comerciais, impondo um limite quando ao nosso debate acerca da ética, em todas as instâncias. Não pode haver ética com exclusão social, bem como não pode haver democracia ampla pelos mesmos motivos. Todo debate sobre ética, desde a justiça, direito até chegar no campo do conhecimento e da ciência é inócuo sem a discussão da inclusão social.

O etnocentrismo, aliado ao niilismo solipsista acreditam em um cosmos sem sentido, fruto do acaso, como se nossas percepções limitadas sobre o que existe, inclusive sobre o que é o planeta Terra, dessem conta da existência, do universo para além de nossos referenciais e categorias analíticas. A apropriação e divulgação de um tipo de conhecimento e informação, em detrimento de vários outros existentes e silenciados ao longo da história, foi um dos primeiros métodos de dominação e de divisão social. Os donos do poder, através da religião, da cultura, do dinheiro, da educação, do entretenimento, dos sistemas políticos, têm nos feito crer que somos diferentes e melhores que os outros, que a pobreza, a miséria, a exclusão são 
Rev. Interd. em Cult. e Soc. (RICS), São Luís, v. 7, n. 1, p. 56- 79, jan./jun. 2021

normais, como se uma atitude de segregação não tivesse repercussão no modelo de vida que escolhemos.

Segundo Eagleton (2021, p. 37):

Umas das razões pelas quais o século XIX tanto meditou sobre o sentido da existência é que em nenhum outro período da história a vida humana valeu tão pouco. Foi de longe a época mais sangrenta nos anais da história, com milhões de mortes desnecessárias. E, se a vida foi tão desvalorizada na prática, surpreende vê-la questionada em teoria? Mas não é só isso. Uma característica da época moderna é que a chamada dimensão simbólica da vida humana foi empurrada para as margens. Nessa dimensão, três áreas eram particularmente importantes: a religião, a cultura e a sexualidade. As três se tornaram menos centrais para a vida pública à medida que a modernidade se desenvolveu. Em sociedades pré-modernas, elas pertenciam às esferas pública e privada. A religião não era apenas uma questão de consciência pessoal e salvação individual, dizia respeito também ao poder estatal, a rituais públicos e ideologias nacionais.

Uma exemplificação deste princípio antiético que está levando à destruição do planeta, que pode ser observada na obra A Queda do Céu, escrita por um indígena Yanomami, Davi Kopenawa e pelo etnólogo francês, Bruce Albert. Em tal obra, a queda do céu é bem mais que a alegoria da devastação da floresta amazônica pelo homem branco, lógico, racional. É a constatação que de o firmamento, simbolizado pelo céu, pode enfim ser arrancado e destroçado, numa demonstração do que as forças plenipotentes da técnica, do "desenvolvimento" 18 e da acumulação do capital são capazes de fazer com o lar que habitamos. A "razão", a lógica investida na tecnologia, subjugou a natureza, fê-la dobrar seus joelhos, sem nenhuma correlação entre os povos que vivem nas florestas, historicamente silenciados, numa ação devastadora de silenciar outras vozes: os seres viventes que dependem das matas, como animais, árvores, interrompidos pelo estampido das engrenagens das máquinas devastadoras.

Porém, o indígena Kopenawa recorre à pele de papel (folhas, retiradas das árvores), para escrever nelas as páginas de uma denúncia, ou seja, recorre a uma linguagem do homem branco para fazê-lo ver o grito da floresta. Para Kopenawa e Bruce (2015, p. 356):

Os brancos talvez pensem que pararíamos de defender nossa floresta caso nos dessem montanhas de suas mercadorias. Estão enganados. Desejar suas coisas tanto quanto eles, só serviria para emaranhar nosso pensamento. Perderíamos nossas próprias palavras e isso nos levaria à morte. Foi o que sempre ocorreu, desde que nossos antigos cobiçaram as suas ferramentas pela primeira vez, há muito tempo. Essa é a verdade. Recusamo-nos a deixar que destruam nossa floresta porque foi Omama que nos fez vir à existência.

\footnotetext{
${ }^{18}$ Segundo Flávio Lazzarin (2009: p. 18): "O que é este desenvolvimento, que retorna como palavras-chaves, após décadas de ostracismo, no dicionário da economia e da política?"
} 
Queremos apenas continuar vivendo nela do nosso jeito, como fizeram nossos ancestrais antes de nós. Não queremos que ela morra, coberta de feridas e dejetos dos brancos. Ficamos com raiva quando eles queimam árvores, rasgam a terra e sujam os rios. Ficamos com raiva quando nossas mulheres, filhos e idosos morrem sem parar de fumaça de epidemia. Não somos inimigos dos brancos. Mas não queremos que venham trabalhar em nossa floresta porque não tem como nos compensar o valor do que aqui destroem. É o que penso.

Se o pensamento dito reflexivo não for capaz de integrar homem-mulher-natureza em seu sentido amplo dentro de um mesmo prisma, é irreflexivo. Se corroborar com preconceitos, estigmatização, e se, sobretudo, for a mola propulsora para qualquer fragmentação, instrumentalização de dominação, seu sentido se torna única e exclusivamente um mecanismo de opressão, ilógica, disfuncional, desviante de sua matriz inicial, portanto, antiética, sem sentido.

Todas essas reflexões, hoje, promovem uma profusão de reverberações que fazem da história anunciadora de novas vozes não mais silenciadas. As prostitutas, os malandros, os boêmios, os transformistas, os homoafetivos, negros e negras, indígenas, pobres em todo o mundo, refugiados, palestinos, as denúncias das violências físicas e simbólicas a que mulheres foram submetidas promovem um duplo movimento: primeiro, apontam para o que não havia sido ocultado, indicando um limite da capacidade reflexiva e biopolítica de colocar diferentes atores em cena; segundo, ao dar vozes ao antes silenciados, estabelecem uma espécie de promoção às outras vozes, ainda que existentes, mudas.

Segundo Borralho (2013):

Há autores ${ }^{19}$ que defendem que a própria noção de humanidade e toda derivação oriunda disso é uma construção discursiva ${ }^{20}$, tal como a vida, a humanidade, a cultura ${ }^{21}$, a igualdade ${ }^{22} \mathrm{e}$ seus correlatos. Enquanto invenção, por que se inventou dessa forma e não de outra? Há respostas plausíveis do tipo: porque um grupo majoritário, dominante, construiu sentidos sociais de dominação política e simbólica e pelo ato da imposição e repetição de seus atos transformaram-se em lógica de dominação social ${ }^{23}$. (p. 89-90)

Sem desmerecer o papel da linguagem ou de negligenciar o condicionante da cultura e da razão enquanto amálgama da noção de humanidade, bem-estar, paz, felicidade, ainda assim, as sociedades humanas foram forjando, ao longo dos tempos, um ideário calcado na ideia da paz em detrimento da

\footnotetext{
${ }^{19}$ DEL ROIO (1998); ARENDT (2002); SANTOS (2013).

${ }^{20}$ Entre eles, WITTGENSTEIN (1975).

${ }^{21}$ Jean Pierre Vernant (2002) explica como se deu tal processo, analisando o mito do milagre grego.

${ }^{22}$ A igualdade entre os povos é uma premissa estabelecida a partir da revolução francesa quando da redação da Declaração Universal dos direitos do Homem, um postulado burguês, visto que a emergência de tal classe reivindicava condições de igualdade jurídica, portanto social, ante o domínio dos aristocratas. Portanto, a ideia de igualdade humana nem sempre existiu. Sobre isso, ver, entre outros: STAROBINSKI (1988).

23 BOBBIO (1987).
} 
Rev. Interd. em Cult. e Soc. (RICS), São Luís, v. 7, n. 1, p. 56- 79, jan./jun. 2021

guerra, da união em detrimento da guerra, da fraternidade em detrimento da disputa, da felicidade em detrimento da tristeza, do amor, segundo Edgar Morin (2001), em detrimento do ódio. (p. 91)

Sócrates no diálogo Fedro, escrito por Platão (2012), poetiza que a cigarra nasceu do homem que, ao conhecer as Musas, pôs-se a cantar como elas até perder a necessidade de sobreviver. Mito transparente, retomado por E. Quinet, que designa o inseto como o "patriarca do canto", mas como esse canto de vida, associado à alegria/adorável/da paz/solar, comparável ao canto do poeta, como única vitória possível sobre a morte, segundo Brunel (2005, p. 125). A quebra do silêncio também é um sinal de vida, afinal, as crianças choram quando nascem.

A cigarra que nasceu do homem e, em contato com as Musas, canta, ou seja, brada, rompe o silêncio e emite sonoridade inconfundível, ininteligível para a linguagem humana, talvez, porque o som emitido pelas cigarras seja a mudez humana antitética, ou melhor, é o silêncio daqueles que com o passar dos anos não são ouvidos.

Ao terminar esse artigo e compilando parte do que já escrevi, dei-me conta de que os

meus textos falam de uma coisa só. No fundo, escrevi um único texto. É a forma de me pronunciar contra os silêncios da história, ainda que reiteradamente.

\section{REFERÊNCIAS}

AGAMBEN, Giorgio. Ideia da prosa. Belo Horizonte: Autêntica, 2012.

ARENDT, Hannah. Entre o passado e o futuro. São Paulo: Perspectiva. 2002.

BAKHTIN, Mikhail. Notas sobre literatura, cultura e ciências humanas: organização, tradução, posfácio e notas de Paulo Bezerra. São Paulo: Editora 34, 2017.

BENJAMIN, Walter. Escritos sobre mito e linguagem. São Paulo: Duas cidades, Editora 34, 2013.

BERGSON, Henri. Matéria e memória. Ensaios sobre a relação do corpo com o espírito. São Paulo: Martins Fontes, 1999.

BERNAL, Martin. Black Athena: The Afroasiatic Roots of Classical Civilization. New Brunswick, New Jersey: Rutgers University Press, 1987.

BOBBIO, Norberto. Estado, governo e sociedade: para uma teoria geral da política. São Paulo: Paz e Terra, 1987

BORRALHO, Henrique. Desejo e criação (parte III). In: Versura.versura.blogspot.com, 2020a. Disponível em: https://versura.blogspot.com/2020/10/desejo-e-criacao-iii.html. Acesso em: 20 de maio de 2021. 
Rev. Interd. em Cult. e Soc. (RICS), São Luís, v. 7, n. 1, p. 56- 79, jan./jun. 2021

ISSN eletrônico: 2447-6498

BORRALHO, Henrique. Filosofia e literatura em Eric Weil. In: PERINE, Marcelo; VALDÉRIO, Francisco; FRANCISCO, Alessandro; BORRALHO, Henrique. Pensamento e História: Michel Foucault, Paul Ricoeur e Eric Weil. São Paulo: Realizações, 2020b. Acesso em 20 de maio de 2021.

BORRALHO, Henrique. Versura: Ensaios. São Luís: EDUEMA \& Café e Lápis, 2017.

BORRALHO, Henrique. História e reflexão. Revista Outros Tempos, São Luís, v. 10, série 16, p. 88-103, 2013.

BORRALHO, Henrique. Mito, História, Contra-história. Ciências Humanas em Revista, São Luís, v. 3. fasc.1, p. 105-126, 2005.

BRUNEL, Pierre. Dicionário de mitos literários. 4. ed. Rio de Janeiro: José Olympio, 2005.

CARTLEDGE, Paul (Org.). História ilustrada da Grécia. Rio de Janeiro: Ediouro, 2002.

DEL ROIO, Marcos. O Império do capital e seus antípodas: a ocidentalização do mundo. São Paulo: Ícone, 1998.

DELUMEAU, Jean. A civilização do Renascimento. Lisboa: Estampa, 1994.

DEUTSCH, D. Quantum Computation. Physics World, Bristol, n. 5, v. 6, p. 57-61, 1992.

DURKHEIM, E. As regras do método sociológico. Tradução de Margarida Garrido Esteves. In: DURKHEIM, E. Os pensadores. São Paulo: Abril Cultural, p. 71-175, 1983.

EAGLETON, Terry. O sentido da vida. Uma brevíssima introdução. Tradução de Pedro Paulo Pimenta. São Paulo: Ed. Unesp, 2021.

FANON, Frantz. Peles negras, máscaras brancas. Tradução de Renato da Silveira. Salvador: EDUFBA, 2008.

FLUSSER, Vilém. Pós-História: vinte instantâneos e um modo de usar. São Paulo: Annablume, 2011.

MACHADO, Roberto. Foucault, a filosofia e a literatura. Rio de Janeiro: Zahar, 2000.

FOUCAULT, Michel. Ditos e Escritos I. Problematização do sujeito: Psicologia, Psiquiatria e Psicanálise. Rio de Janeiro: Forense Universitária, 1999.

JAEGER, Werner. Paidéia: A formação do Homem Grego. Tradução de Artur M. Parreira. 4. ed. São Paulo: Martins Fontes, 2001.

KOPENAWA, Davi; ALBERT, Bruce. A queda do céu: palavras de um xamã yanomami. Tradução de Beatriz Perrone-Moisés; prefácio de Eduardo Viveiros de Castro. 1. ed. São Paulo: Companhia das Letras, 2015. 
Rev. Interd. em Cult. e Soc. (RICS), São Luís, v. 7, n. 1, p. 56- 79, jan./jun. 2021

ISSN eletrônico: 2447-6498

KOSELLECK, Reinhart. Futuro passado: contribuição à semântica dos tempos históricos. Rio de Janeiro: Contraponto; Ed. PUC-Rio, 2012.

HALBWACHS, Maurice. A memória coletiva. São Paulo: Vértice, 1990.

LAPLANTINE, Françoise. Aprender Antropologia. São Paulo: Brasiliense, 2000.

LAZZARIN, Flávio. Processo de colonização e lutas descolonizadoras no Brasil de hoje. CONFERÊNCIA DE ABERTURA DO I SIMPÓSIO INTERNACIONAL: BRASIL E ITÁLIA: CRUZAMENTOS TRANSATLÂNTICOS E QUESTÕES

INTERDISCIPLINARES, 2015. São Luís-MA, Anais [...] São Luís: UFMA-prédio de História, 26 ago. 2015.

LAZZARIN, Flávio. Desfazer o desenvolvimento e refazer o mundo: uma provocação para o debate. In: CARNEIRO, Marcelo Sampaio; COSTA, Cabral Wagner (Org.). A terceira margem do rio. Ensaios sobre a realidade do Maranhão no novo milênio. São Luís: EDUFMA, Instituto EKOS, 2009.

LE GOFF, Jacques. História e memória. Tradução de Bernardo Leitão. 4. ed. Campinas: Ed. Unicamp, 1996.

LIPOVETSKY, Gilles. A sociedade da decepção. Lisboa: Edições 70, 2006.

MACHADO, Roberto. Foucault, a filosofia e a literatura. Rio de Janeiro: JZE, 2000.

MARTINS, Mirkos Ortiz; VIZZOTTO, Juliana Kaiser; LIBRELLOTO, Giovan Rubert. Simulando o modelo ORCH-OR através de autômatos celulares quânticos. Revista Brasileira de Computação Aplicada, Passo Fundo, v. 3, n. 1, mar., p. 74-81, 2011.

MARX, Karl. Manuscritos econômicos e filosóficos. São Paulo: Martin Claret. 2003.

MBEMBE, Achile. A crítica da razão negra. Tradução de Maria Lança. 3. ed. Lisboa: Antígona, 2014.

MIGNOLO, Walter. Histórias locais. Projetos globais. Colonialidade, saberes subalternos e pensamento liminar. Belo Horizonte: Ed. da UFMG, 2013.

NUNES, Benedito. Hermenêutica e poesia. O pensamento poético. Organização de Maria José Campos. 2a reimpressão. Belo Horizonte, UFMG, 2011.

PERROT, Michelle. Os excluídos da História: operários, mulheres, prisioneiros. 3. ed. São Paulo: Paz e Terra, 2001.

PLATÃO, Fedro. Tradução, apresentação e notas de Edson Bini. São Paulo: Edipro, 2012.

PUGLIESI, Márcio. Mitologia greco-romana: arquétipo dos deuses e heróis. São Paulo: Madras, 2003.

RICOEUR, Paul. A memória, a história, o esquecimento. Tradução de Alain François. São Paulo: Ed. Unicamp, 2008. 
Rev. Interd. em Cult. e Soc. (RICS), São Luís, v. 7, n. 1, p. 56- 79, jan./jun. 2021

ISSN eletrônico: 2447-6498

ROCHA, Filipe. Teorias sobre a História. Braga: Editorial Franciscana Montariol. 1982.

SANTOS, Boaventura Sousa. A crítica da razão indolente: contra o desperdício da experiência. 2. ed. São Paulo: Cortez, 2000.

SANTOS, Boaventura Sousa. Pela mão de Alice: o social e o político na pósmodernidade. São Paulo, Cortez, 2001.

SCHLEGEL, Friedrich. Sobre o estudo da poesia grega. Tradução de Constantino Luiz de Medeiros.

São Paulo: Iluminuras, 2018.

SNELL, Bruno. A cultura grega e as origens do pensamento europeu. São Paulo: Perspectiva, 2002.

STANDART \& POOR'S pagará multa de US\$ 1,37 bi por seu papel em crise. 03/02/2015. In: G1 Ecomomia. Disponível em: http://g1.globo.com/economia/negocios/noticia/2015/02/standardpoors-pagara-multa-de-us-137-bi-por-seu-papel-em-crise.html. Acesso em: 20 de maio de 2021.

STAROBINSKI, Jean. 1789: os emblemas da razão. São Paulo: Cia. Das Letras, 1988.

TODOROV, Tzvetan. A conquista da América: a questão do outro. Tradução de Beatriz Perrone-Moisés. 2. ed. São Paulo: Martins Fontes, 1993.

TUAN, Yu-Fu. Topofilia: um estudo da percepção, atitudes e valores do meio ambiente. São Paulo: EDUEL, 2012.

WEIL, Eric. Lógica da Filosofia. São Paulo: É Realizações, 2012.

WEIL, Pierre. Nova linguística holística. Rio de Janeiro: Espaço e Tempo, 1987.

VAINFAS, Ronaldo. Os protagonistas anônimos da História. Rio de Janeiro: Campus, 2002.

VERAS, Elias Ferreira; PEDRO, Joana Maria. Os silêncios de Clio: escrita da história e (in)visibilidade das homossexualidades no Brasil. Revista Tempo e Argumento, Florianópolis, v. 6, n.13, set./dez., p. 90- 109, 2014.

VERNANT, Jean-Pierre. Entre mito e política. São Paulo: EDUSP, 2002.

WITTGENSTEIN, Ludwig. Investigações filosóficas. São Paulo: Abril Cultural, 1975. 